\title{
DNA Ligation
}

National Cancer Institute

\section{Source}

National Cancer Institute. DNA Ligation. NCI Thesaurus. Code C19246.

The joining together of two or more nucleic acid molecules by the action of ligase 